\title{
Comparative analysis of citrus fruits for nutraceutical properties
}

\author{
Shams Ur REHMAN ${ }^{1,2}$, Kashif Sarfraz ABBASI ${ }^{2}$, Abdul QAYYUM ${ }^{3 *}$ (D), Muhammad JAHANGIR ${ }^{1}$, Asma SOHAIL ${ }^{2}$, \\ Sobia Nisa ${ }^{4}$, Muhammad Naveed TAREEN ${ }^{5}$, Muhammad Javed TAREEN ${ }^{5}$, Peter SOPADE ${ }^{6}$
}

\begin{abstract}
Fruits and vegetables ( $\mathrm{F}$ and $\mathrm{V}$ ) are valuable for their micronutrients, but many $\mathrm{F}$ and $\mathrm{V}$ in diverse growth areas have not been scientifically validated for these components. The nutraceutical characteristics of the pulp of eight citrus fruits grown in Pakistan were, therefore, investigated. Expectedly, the fruits differed in moisture (86.9-88.9\%), ash (0.37-0.53\%), pH (2.9-5.8), total soluble solids (8.1-13.7 $\left.{ }^{\circ} \mathrm{Brix}\right)$, titratable acidity (7.9-13.1\%), total sugars (5.1-8.8\%), reducing sugars (2.8-4.3\%), and non-reducing sugars (0.3-0.5\%) contents. Potassium, sodium and magnesium were the major minerals, while iron, zinc and manganese were present in minor fractions in the pulps. Phytochemical analysis (total phenolic content, 132-243 $\mu \mathrm{g} / \mathrm{g} \mathrm{GAE}$; total flavonoids content, 4.2-12.1 $\mu \mathrm{g} / \mathrm{g}$ QE; vitamin C, 36.3-62.3 mg/100 g) revealed antioxidant potential that was confirmed by a high 1, 1-diphenyl 1-2-picrylhydrazyl (DPPH) radical scavenging activity, showing a highly positive correlation $\left(\mathrm{r}^{2}>0.921,0.917,0.807 \mathrm{p}>0.05\right)$ with the measured antioxidant components (Total Phenolics, Total Flavonoids and vitamin C). Principal component analysis shows a significant relationship between the citrus varieties and their quality parameters to guide their industrial potential as sources of nutraceuticals.
\end{abstract}

Keywords: antioxidant potential; Citrus spp.; major minerals; principal component analysis.

Practical Application: Physiochemical attributes of citrus varieties.

\section{Introduction}

Citrus fruits (Rutaceae) are popularly grown all over the world and sub-divided into 78 species, with their distinctive and varied flavors (Texeira et al., 2005; Okwi \& Emenike, 2006). Fruit characteristics are one of the important parameters used for the selection of best genotypes for further propagations (Paudyal \& Haq, 2008), and total soluble solid is an important economic index, especially with frozen concentrates (Rouse, 2000). Citrus fruits are mostly considered as acid fruits, since their soluble solids are composed mainly of organic acids and sugars (Kelebek et al., 2009). The acid content of juices is an important quality and maturity index (Song et al., 2016), and as with other fruit characteristics, it depends on fruit varieties, cultural practices and climate, amongst others (Burdurlu et al., 2006). Citrus fruits are also important because of their constituents with antioxidant potential, which have been investigated with different in-vitro assays such as DPPH radical scavenging activity (Zou et al., 2016). There are also anticancer (e.g. taxol), chemotherapic, antiviral, and anti-inflammatory components, and other bioactive constituents, which make citrus fruits valuable ingredients in functional foods (Ismail et al., 2004; Xu et al., 2008).

The Rawalpindi region (Taxila valley) of Pakistan is well known for its citrus fruits with a viable local industry based on the produce (Siddique \& Garnevska, 2017). The region produces many citrus varieties, and with environmental factors exercising well-known effects on quality and characteristics of agricultural produce, a study on the citrus varieties from the region is important to understand how the unique citrus varieties in the region, and how the well-known varieties compare with other from other regions or places. We are not aware of any detailed study along these lines, and the present study reports quality attributes of eight citrus varieties from the region that were chosen because of their perceived unique characteristics.

\section{Materials and methods}

\subsection{Materials}

Eight citrus varieties, Citrus sinensis cv (Hamlin, Red blood, Succuri), Citrus limetta (Mosambi), Citrus reticulate (Tangerine), Citrus paradise macfed (Grape fruit), Citrus aurantium and Citrus jambhiri lush, were collected from the Rawalpindi Region of Pakistan. The fruits were washed, sorted, graded, and stored at room temperature till further analysis. The fruits were pulped prior to analysis.

\subsection{Chemical analysis}

Total soluble solid (TSS as ${ }^{\circ} \mathrm{Brix}$ ) was determined (Association of Official Analytical Chemists, 2005) using a digital refractometer PAL-3 (ATAGO, Japan) at $29 \pm 1{ }^{\circ} \mathrm{C}$ with temperature corrections. 
$\mathrm{pH}$ (pH-meter, Inolab. WTW Series, Germany), titratable acidity (TA), total sugars (TS) and reducing sugars (RS) (Lane and Eynon titration method, Fehling's solutions), moisture content (Model: 605, Precision Oven, Thermo Fisher Scientific; $105^{\circ} \mathrm{C}$ till constant weight), ash content (muffle furnace, lef-2055-0, Daihan Labtech, Korea, $550{ }^{\circ} \mathrm{C}$ ), crude fiber (gravimetric enzymatic digestion procedure) were measured (Association of Official Analytical Chemists, 2005). The mineral content was determined (Association of Official Analytical Chemists, 2005) by digesting $5 \mathrm{~g}$ of the pulp with $10 \mathrm{~mL}$ of a nitric acid:perchloric acid (7:3) mixture at $180-200{ }^{\circ} \mathrm{C}$ till completion. The digest was made up to $100 \mathrm{~mL}$ with distilled water, and $\mathrm{Mg}, \mathrm{Fe}, \mathrm{Zn}$, and $\mathrm{Mn}$ contents of the pulp were determined in an Atomic Absorption Spectrophotometer (GBC-932, Scientific Equipment Limited, Australia), whereas $\mathrm{Na}$ and $\mathrm{K}$ were measured by Flame Photometer (Model PFP 7, Jenway, England). Vitamin C was also determined (Association of Official Analytical Chemists, 2005).

\subsection{Phytochemical analysis}

\section{Sample preparation}

During the extraction of antioxidants from the citrus pulp samples, methanol was used to assess their extraction efficiency. The samples were subjected to orbital shaker for $7 \mathrm{hr}$ followed by centrifugation (model: 800 electronic centrifuge, RENONLAB) $1342 \mathrm{~g}$ for $10 \mathrm{~min}$. The supernatant was decanted, and the residue was re-dissolved in $10 \mathrm{~mL}$ of the methanol and centrifuged for $5 \mathrm{~min}$., before combining both supernatants (extracts) for the following analyses (Rusak et al., 2008):

\section{Total Phenolic Content (TPC)}

One $\mathrm{mL}$ of the extract was oxidized with $2.5 \mathrm{~mL}$ of Folin-Ciocalteau's reagent (10\%), followed by neutralization with $2 \mathrm{~mL}$ sodium carbonate (7.5\%). The mixture was kept in the dark for $45 \mathrm{~min}$., and the absorbance was measured at $765 \mathrm{~nm}$ wavelength using a spectrophotometer (UV-9200, Biotech Engineering Management Co., UK). Gallic acid (ug/g) was used as the standard (Anagnostopoulou et al., 2006).

\section{Total Flavonoids Content (TFC)}

One $\mathrm{mL}$ of the extract was mixed with $0.3 \mathrm{~mL}$ of sodium nitrite (5\%). After an interval of $5 \mathrm{~min}$., $0.6 \mathrm{~mL}$ of aluminum chloride $(10 \%)$ was added and mixed. This was followed by adding
$2 \mathrm{~mL}$ of $1 \mathrm{M}$ sodium hydroxide after an interval of $5 \mathrm{~min}$., and the absorbance was measured at $510 \mathrm{~nm}$ wavelength with the spectrophotometer. The total flavonoid was calculated using quercetin (ug/g) as a standard (Toh et al., 2013).

\section{1, 1-diphenyl 1-2-picrylhydrazyl (DPPH) radical scavenging assay}

An equal volume of the extract was added to methanolic solution of DPPH $(0.7 \mathrm{mM})$ and held for $30 \mathrm{~min}$. at room temperature before the absorbance was measured at $517 \mathrm{~nm}$ using the spectrophotometer. The percent of radical scavenging activity was calculated as the ratio of the absorbance of the sample, $\mathrm{A}_{\text {sample }}$, relative to the control, $\mathrm{A}_{\text {control }}$ (Mishra et al., 2012). The control was the DPPH solution without the fruit extract, and the radical scavenging activity (\%) was calculated as Equation 1:

Radical scavenging activity $(\%)=100 \times\left(\mathrm{A}_{\text {control }}-\mathrm{A}_{\text {sample }}\right) / \mathrm{A}_{\text {control }}$

\subsection{Statistical analysis}

Results were subjected to one-way analysis of variance (ANOVA). Statistical differences with P-values less than 0.05 were considered significant and means were compared by LSD test according to Steel et al. (1997). Principal component analysis was performed by using SIMCA-P software. All analyses on the pulps were triplicated.

\section{Results and discussion}

Knowledge about biochemical composition of citrus pulp in different varieties is very important for various purposes including measuring maturity indices (Rouse, 2000), chemical profiling of citrus fruits (Álvarez et al., 2014), its antioxidant potential (Ortuño et al., 1997), mineral profiling (Barros et al., 2012), conversions of citrus fruit to different products and its taste characterization.

\subsection{Chemical constituents}

Table 1 shows the results for the moisture, $\mathrm{pH}$, TSS, TA, TS, RS, NRS, and crude fiber, and there were varietal differences. The moisture content of the pulps is within the range (85.8-87.9\%)

Table 1. Chemical components of the citrus varieties".

\begin{tabular}{|c|c|c|c|c|c|c|c|c|}
\hline Variety & Moisture \% & $\mathrm{pH}$ & TSS $^{\circ}$ & TA $\%$ & TS $\%$ & RS \% & NRS \% & CF \% \\
\hline $\mathrm{CSH}$ & $87.7 \pm 0.6 \mathrm{bc}$ & $3.79 \pm 0.06 \mathrm{~d}$ & $11.4 \pm 0.2 \mathrm{c}$ & $1.01 \pm 0.05 \mathrm{~d}$ & $11.1 \pm 0.4 \mathrm{c}$ & $7.33 \pm 0.2 b c$ & $3.71 \pm 0.3 b c$ & $0.31 \pm 0.005 \mathrm{e}$ \\
\hline CSR & $88.8 \pm 0.4 \mathrm{a}$ & $4.17 \pm 0.03 c$ & $11.1 \pm 0.3 \mathrm{c}$ & $0.91 \pm 0.03 \mathrm{~d}$ & $10.59 \pm 0.4 \mathrm{c}$ & $6.90 \pm 0.2 \mathrm{~d}$ & $3.69 \pm 0.2 b c$ & $0.31 \pm 0.007 e$ \\
\hline CSS & $86.1 \pm 0.4 \mathrm{e}$ & $5.85 \pm 0.07 \mathrm{a}$ & $13.6 \pm 0.3 \mathrm{a}$ & $0.23 \pm 0.02 \mathrm{f}$ & $13.1 \pm 0.3 \mathrm{a}$ & $8.76 \pm 0.1 \mathrm{a}$ & $4.31 \pm 0.2 \mathrm{a}$ & $0.41 \pm 0.011 b$ \\
\hline CLM & $87.5 \pm 0.3 \mathrm{~cd}$ & $4.43 \pm 0.05 b$ & $12.2 \pm 0.4 \mathrm{~b}$ & $0.58 \pm 0.02 \mathrm{e}$ & $11.8 \pm 0.2 b$ & $7.63 \pm 0.2 b$ & $4.21 \pm 0.1 \mathrm{ab}$ & $0.41 \pm 0.009 b$ \\
\hline CRT & $88.4 \pm 0.5 \mathrm{ab}$ & $4.41 \pm 0.04 \mathrm{~b}$ & $11.2 \pm 0.4 \mathrm{c}$ & $0.54 \pm 0.02 \mathrm{e}$ & $10.8 \pm 0.6 \mathrm{c}$ & $7.23 \pm 0.1 \mathrm{~cd}$ & $3.57 \pm 0.5 c$ & $0.33 \pm 0.004 c$ \\
\hline CPM & $87.1 \pm 0.2 \mathrm{~cd}$ & $3.40 \pm 0.05 \mathrm{e}$ & $11.2 \pm 0.3 \mathrm{c}$ & $1.82 \pm 0.07 c$ & $11.2 \pm 0.2 b c$ & $7.16 \pm 0.1 \mathrm{~cd}$ & $4.11 \pm 0.1 \mathrm{ab}$ & $0.37 \pm 0.009 c$ \\
\hline CAT & $86.9 \pm 0.1 \mathrm{~d}$ & $2.96 \pm 0.05 g$ & $8.1 \pm 0.1 \mathrm{~d}$ & $4.46 \pm 0.08 \mathrm{a}$ & $7.85 \pm 0.12 \mathrm{~d}$ & $5.06 \pm 0.2 \mathrm{e}$ & $2.78 \pm 0.2 \mathrm{~d}$ & $0.26 \pm 0.006 f$ \\
\hline CJL & $87.1 \pm 0.2 \mathrm{~cd}$ & $3.15 \pm 0.03 f$ & $8.5 \pm 0.2 \mathrm{~d}$ & $4.08 \pm 0.12 b$ & $8.19 \pm 0.17 \mathrm{~d}$ & $5.26 \pm 0.1 \mathrm{e}$ & $2.93 \pm 0.2 \mathrm{~d}$ & $0.54 \pm 0.007 \mathrm{a}$ \\
\hline
\end{tabular}

${ }^{*}$ Dissimilar letters within a column indicate significant differences $(\mathrm{p} \leq 0.05)$. Values are means of three measurements \pm standard errors. TSS $=$ total soluble solids; TA = titratable acidity; TS = total sugars; RS = reducing sugars; $\mathrm{NRS}=$ non-reducing sugars; $\mathrm{CF}=\mathrm{crude}$ fibre; $\mathrm{CSH}=\mathrm{Citrus}$ sinensis $\mathrm{cv}$ hamlin; CSR = Citrus sinensis $\mathrm{cv}$ red blood; CSS = Citrus sinensis cv succuri; CLM = Citrus limetta mosambi; CRT = Citrus raticulata tangerine; $\mathrm{CPM}=$ Citrus paradise macfed; CAT $=$ Citrus aurantium $\mathrm{L} ; \mathrm{CJL}=$ Citrus jambhiri lush. These apply to all tables and figure where they appear. 
reported by Barros et al. (2012) for citrus varieties, and moisture content of citrus fruits determines their freshness and keeping quality (Chien et al., 2007). The results on the other parameters of the pulps also agree with findings from previous studies (Álvarez et al., 2014; Barros et al., 2012), and genotype and environmental differences are not uncommon between and within agricultural produce (Petropoulos et al., 2018). The Citrus sinensis $\mathrm{cv}$ succuri had the highest TSS $\left(13.6^{\circ} \mathrm{Brix}\right), \mathrm{TS},(13.1 \%)$, RS (8.76\%), NRS (4.31\%) and $\mathrm{pH}$ (5.85), and it is generally the sweetest amongst the eight citrus varieties. On the other hand, the CAT (Citrus aurantium $\mathrm{L}$ ) is generally the most bitter of the varieties, and this could be due to it having the lowest values in the parameters studied (TSS, $8.1^{\circ} \mathrm{Brix}$; TS, 7.85\%; RS, 5.06\%; NRS, $2.78 \% ; \mathrm{pH}, 2.96)$. The solid and sugar parameters are positively correlated $\left(\mathrm{r}^{2}>0.88 ; \mathrm{p}>0.05\right)$, and the $\mathrm{pH}$ and the TA are negatively correlated $\left(\mathrm{r}^{2}>-0.85 ; \mathrm{p}>0.05\right)$, the $\mathrm{pH}$ is positively $\left(r^{2}>0.050 .65 ; p>0.05\right)$ and the TA is negatively $\left(r^{2}>-0.82\right.$; $\mathrm{p}>0.05)$ correlated with the total soluble solids and total sugar parameters. Seymour et al. (2012) observed that high pH and TSS are indications of sweetness, while more tartness in citrus fruits manifests in high TA.

\subsection{Antioxidant properties}

Table 2 summarizes the antioxidant parameters of the citrus pulps that are variety dependent and are within published ranges (Burdurlu et al., 2006; Barros et al., 2012). The Citrus sinensis succuri had the highest values, while the Citrus jambhiri lush was the least in nearly all the parameters. Table 3 shows the correlations between these antioxidant parameters, and the highly significant correlations obtained, similar to those reported elsewhere (Xu et al., 2008), indicate how the antioxidant components are good predictors of antioxidant capacities, as expected.

\subsection{Mineral components}

Citrus fruits are highly nutritious owing to its significant mineral potential as Table 4 shows the major and trace minerals in the pulps, which are also variety dependent, and within the ranges of Barros et al. (2012). Potassium is the principal mineral in the pulps $(103.9-172.9 \mathrm{mg} / 100 \mathrm{~g})$, while sodium is relatively much lower $(1.6-2.8 \mathrm{mg} / 100 \mathrm{~g})$. The balance between these minerals in citrus plays an important role in balancing electrolytes in human cells (Ladaniya, 2008). The pulps contained more

Table 2. Antioxidant properties of the citrus varieties".

\begin{tabular}{ccccc}
\hline Variety & DPPH \% & TPC ug/g & TFC ug/g & Vit C mg/100 mL \\
\hline CSH & $64.8 \pm 1.8 \mathrm{ab}$ & $222.3 \pm 3.6 \mathrm{c}$ & $9.93 \pm 0.46 \mathrm{c}$ & $57.4 \pm 1.8 \mathrm{~b}$ \\
CSR & $63.6 \pm 1.7 \mathrm{~b}$ & $207.0 \pm 4.8 \mathrm{~d}$ & $9.04 \pm 0.17 \mathrm{~d}$ & $53.2 \pm 1.3 \mathrm{c}$ \\
CSS & $66.4 \pm 1.2 \mathrm{a}$ & $243.3 \pm 1.8 \mathrm{a}$ & $12.1 \pm 0.56 \mathrm{a}$ & $61.6 \pm 1.5 \mathrm{a}$ \\
CLM & $65.3 \pm 2.6 \mathrm{ab}$ & $234.6 \pm 2.5 \mathrm{~b}$ & $10.9 \pm 0.40 \mathrm{~b}$ & $62.3 \pm 1.6 \mathrm{a}$ \\
CRT & $60.1 \pm 1.2 \mathrm{c}$ & $180.6 \pm 3.1 \mathrm{e}$ & $7.67 \pm 0.32 \mathrm{e}$ & $49.6 \pm 1.3 \mathrm{~d}$ \\
CPM & $58.6 \pm 1.2 \mathrm{c}$ & $165.6 \pm 4.3 \mathrm{f}$ & $6.15 \pm 0.21 \mathrm{f}$ & $38.9 \pm 1.5 \mathrm{f}$ \\
CAT & $58.6 \pm 1.3 \mathrm{c}$ & $158.9 \pm 3.1 \mathrm{~g}$ & $5.10 \pm 0.14 \mathrm{~g}$ & $36.3 \pm 1.1 \mathrm{f}$ \\
CJL & $55.3 \pm 2.1 \mathrm{~d}$ & $132.6 \pm 2.9 \mathrm{~h}$ & $4.18 \pm 0.18 \mathrm{~h}$ & $43.9 \pm 1.3 \mathrm{e}$ \\
\hline
\end{tabular}

"Dissimilar letters within a column indicate significant differences $(\mathrm{p} \leq 0.05)$. Values are means of three measurements \pm standard errors. DPPH $=1,1$-diphenyl 1-2-picrylhydrazyl; $\mathrm{TPC}=$ total phenolic content; TFC = total flavonoids content; Vit C = vitamin C; $\mathrm{CSH}=$ Citrus sinensis $\mathrm{cv}$ hamlin; $\mathrm{CSR}=$ Citrus sinensis $\mathrm{cv}$ red blood; $\mathrm{CSS}=$ Citrus sinensis $\mathrm{cv}$ succuri; $\mathrm{CLM}=$ Citrus limetta mosambi; $\mathrm{CRT}=$ Citrus raticulata tangerine; $\mathrm{CPM}=$ Citrus paradise macfed; $\mathrm{CAT}=$ Citrus aurantium $\mathrm{L} ; \mathrm{CJL}=$ Citrus jambhiri lush.

Table 3. Correlation between the antioxidant properties of the citrus varieties.

\begin{tabular}{clll}
\hline & DPPH & TPC & TFC \\
\hline TPC & $0.921^{\star}$ & & $0.984^{* \star}$ \\
TFC & $0.917^{*}$ & $0.916^{\star}$ & $0.890^{\star}$ \\
Vit C & $0.807^{\star}$ & & \\
\hline
\end{tabular}

Significant at $\mathrm{p}<0.05^{\star}$; Significant at $\mathrm{p}<0.001^{\star *}$. DPPH $=1,1$-diphenyl 1-2-picrylhydrazyl; TPC = total phenolic content; TFC = total flavonoids content; Vit C = vitamin C.

Table 4. Mineral components of the citrus varieties".

\begin{tabular}{clllllll}
\hline Variety & Ash $\%$ & $\mathrm{Na} \mathrm{mg} / 100 \mathrm{~g}$ & $\mathrm{~K} \mathrm{mg} / 100 \mathrm{~g}$ & $\mathrm{Mg} \mathrm{mg} / 100 \mathrm{~g}$ & $\mathrm{Fe} \mathrm{mg} / 100 \mathrm{~g}$ & $\mathrm{Zn} \mathrm{mg} / 100 \mathrm{~g}$ & $\mathrm{Mn} \mathrm{mg} / 100 \mathrm{~g}$ \\
\hline CSH & $0.42 \pm 0.01 \mathrm{bc}$ & $2.17 \pm 0.05 \mathrm{~d}$ & $146 \pm 7.6 \mathrm{bc}$ & $9.96 \pm 0.4 \mathrm{bc}$ & $0.17 \pm 0.005 \mathrm{~d}$ & $0.094 \pm 0.003 \mathrm{~b}$ & $0.047 \pm 0.003 \mathrm{c}$ \\
CSR & $0.37 \pm 0.01 \mathrm{~d}$ & $2.55 \pm 0.09 \mathrm{~b}$ & $141 \pm 3.2 \mathrm{c}$ & $10.3 \pm 0.1 \mathrm{~b}$ & $0.25 \pm 0.005 \mathrm{~b}$ & $0.066 \pm 0.003 \mathrm{de}$ & $0.055 \pm 0.002 \mathrm{~b}$ \\
CSS & $0.52 \pm 0.01 \mathrm{a}$ & $2.87 \pm 0.04 \mathrm{a}$ & $172 \pm 4.2 \mathrm{a}$ & $8.56 \pm 0.5 \mathrm{~d}$ & $0.17 \pm 0.003 \mathrm{~d}$ & $0.093 \pm 0.004 \mathrm{~b}$ & $0.039 \pm 0.003 \mathrm{de}$ \\
CLM & $0.44 \pm 0.02 \mathrm{bc}$ & $1.69 \pm 0.05 \mathrm{f}$ & $103 \pm 7.5 \mathrm{e}$ & $4.93 \pm 0.1 \mathrm{f}$ & $0.11 \pm 0.004 \mathrm{~g}$ & $0.066 \pm 0.005 \mathrm{de}$ & $0.035 \pm 0.002 \mathrm{ef}$ \\
CRT & $0.53 \pm 0.02 \mathrm{a}$ & $2.84 \pm 0.06 \mathrm{a}$ & $146 \pm 6.1 \mathrm{bc}$ & $9.66 \pm 0.3 \mathrm{c}$ & $0.15 \pm 0.004 \mathrm{e}$ & $0.069 \pm 0.003 \mathrm{~cd}$ & $0.046 \pm 0.002 \mathrm{c}$ \\
CPM & $0.40 \pm 0.02 \mathrm{~cd}$ & $2.41 \pm 0.04 \mathrm{c}$ & $139 \pm 4.1 \mathrm{c}$ & $7.78 \pm 0.4 \mathrm{e}$ & $0.18 \pm 0.005 \mathrm{c}$ & $0.073 \pm 0.003 \mathrm{c}$ & $0.041 \pm 0.004 \mathrm{~d}$ \\
CAT & $0.43 \pm 0.02 \mathrm{bc}$ & $1.98 \pm 0.04 \mathrm{e}$ & $117 \pm 4.4 \mathrm{~d}$ & $5.32 \pm 0.1 \mathrm{f}$ & $0.12 \pm 0.004 \mathrm{f}$ & $0.061 \pm 0.003 \mathrm{e}$ & $0.032 \pm 0.003 \mathrm{f}$ \\
CJL & $0.45 \pm 0.03 \mathrm{~b}$ & $2.77 \pm 0.06 \mathrm{a}$ & $153 \pm 4.3 \mathrm{~b}$ & $11.7 \pm 0.2 \mathrm{a}$ & $0.27 \pm 0.005 \mathrm{a}$ & $0.101 \pm 0.004 \mathrm{a}$ & $0.068 \pm 0.006 \mathrm{a}$ \\
\hline
\end{tabular}

"Dissimilar letters within a column indicate significant differences $(\mathrm{p} \leq 0.05)$. Values are means of three measurements \pm standard errors. $\mathrm{Na}=\mathrm{Sodium}$; $\mathrm{K}=\mathrm{Potassium} ; \mathrm{Mg}=\mathrm{Magnesium}$; $\mathrm{Fe}=$ Iron; $\mathrm{Zn}=\mathrm{Zinc} ; \mathrm{Mn}=$ Manganese; $\mathrm{CSH}=$ Citrus sinensis $\mathrm{cv}$ hamlin; $\mathrm{CSR}=$ Citrus sinensis $\mathrm{cv}$ red blood; CSS = Citrus sinensis $\mathrm{cv}$ succuri; $\mathrm{CLM}=$ Citrus limetta mosambi CRT = Citrus raticulata tangerine; $\mathrm{CPM}=$ Citrus paradise macfed; $\mathrm{CAT}=$ Citrus aurantium $\mathrm{L} ; \mathrm{CJL}=$ Citrus jambhiri lush. 


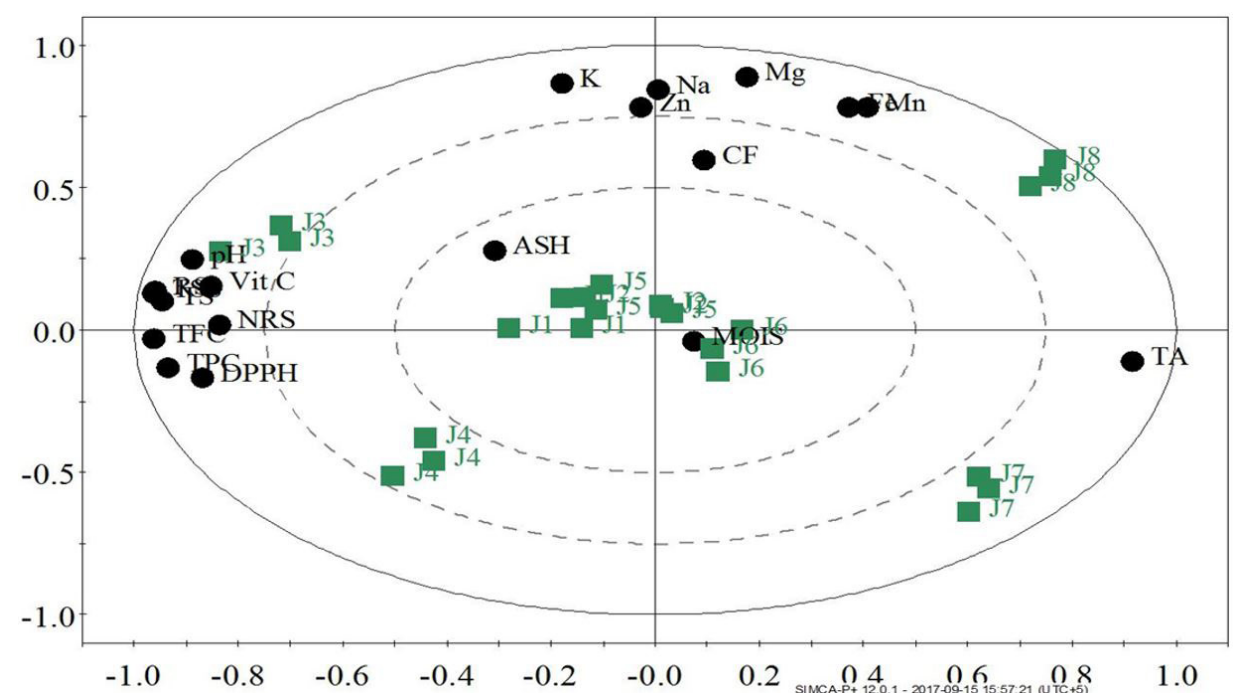

Figure 1. J1 = (CSH) Citrus sinensis Hamlin; J2 = (CSR) Citrus sinensis Red Blood; J3 = (CSS) Citrus sinensis Succuri; J4 = (CLM) Citrus limetta mosambi; J5 = (CRT) Citrus reticulate Tangerine; J6 = (CPM) Citrus paradise Macfed; J7 = (CAT) Citrus aurantium; J8 $=(\mathrm{CJL})$ Citrus jambhiri Lush; DPPH = 1, 1-diphenyl 1-2-picrylhydrazyl; TPC = total phenolic content; TFC = total flavonoids content; Vit C = vitamin C; TS = total sugars; $\mathrm{CF}=$ crude fibre; $\mathrm{MOIS}=$ moisture; $\mathrm{TA}=$ titratable acidity; $\mathrm{NRS}=$ non-reducing sugars; $\mathrm{Na}=$ Sodium; $\mathrm{K}=\mathrm{Potassium} ; \mathrm{Mg}=\mathrm{Magnesium}$; $\mathrm{Fe}=$ Iron; $\mathrm{Zn}=\mathrm{Zinc} ; \mathrm{Mn}=$ Manganese .

magnesium (4.9-11.7 mg/100 g) than sodium. Antioxidant abilities depend on micronutrients, and some minerals are components of antioxidants enzymes, for example, superoxide dismutase depends on $\mathrm{Mn}$ and $\mathrm{Zn}$, and catalase depends on Fe (Evans \& Halliwell, 2001). Hence, quantifying these minerals present a holistic view of the antioxidant potential of these citrus varieties.

\subsection{Multivariate analysis}

Data obtained from citrus varieties based on chemical, elemental and antioxidant components were analyzed by the principal component analysis (Figure 1). Multivariate data analysis brings the data together and distinguishes the varieties and treatments into groups. The PCA showed the Citrus sinensis $\mathrm{cv}$ succuri (J3) with high amounts of the antioxidant and chemical components, except its low TA, while the Citrus aurantium L (J7) and Citrus jambhiri lush (J8) showed the opposite trends. The Citrus paradise macfed (J6) gave the most dilute pulps (high moisture), and the crude fibre and mineral values were segregated with slightly close association with the Citrus jambhiri lush (J8).

\section{Conclusions}

From the eight citrus varieties of the Rawalpindi district of Pakistan, differences were measured in the chemical, antioxidant and mineral components. The Citrus sinensis cv succuri was effectively the best in the tested components. The Citrus jambhiri lush had the highest contents of magnesium, iron, zinc, and manganese. The study revealed functional potential of citrus fruits to be used in different nutraceutical product development. Varietal characterization would also be helpful in the development of targeted commercial products. In addition, correlations in the studied quality attributes will offer better understanding of post-harvest physiology of citrus fruits.

\section{Acknowledgements}

The authors acknowledge Department of Food Technology, PMAS-Arid Agriculture University, Rawalpindi, Pakistan, for providing facilities for the completion of this research work.

\section{References}

Álvarez, J., Pastoriza, S., Alonso-Olalla, R., Delgado-Andrade, C., \& Rufián-Henares, J. A. (2014). Nutritional and physicochemical characteristic of commercial spanish citrus juices. Food Chemistry, 164, 396-405. http://dx.doi.org/10.1016/j.foodchem.2014.05.047. PMid:24996350.

Anagnostopoulou, M. A., Kefalas, P., Papageorgiou, V. P., Assimopoulou, A. N., \& Boskou, D. (2006). Radical scavenging activity of various extracts and fractions of sweet orange peel (Citrus sinensis). Food Chemistry, 94(1), 19-25. http://dx.doi.org/10.1016/j.foodchem.2004.09.047.

Association of Official Analytical Chemists - AOAC. (2005). Official method of analysis (18th ed.). Gaithersburg: AOAC Press.

Barros, H. R. M., Ferreira, T. A. P. C., \& Genovese, M. (2012). Antioxidant capacity and mineral content of pulp and peel from commercial cultivars of citrus from Brazil. Food Chemistry, 134(4), 1892-1898. http://dx.doi.org/10.1016/j.foodchem.2012.03.090. PMid:23442635.

Burdurlu, H. S., Koca, N., \& Karadeniz, F. (2006). Degradation of vitamin $\mathrm{c}$ in citrus juice concentrates during storage. Journal of Food Engineering, 74(2), 211-216. http://dx.doi.org/10.1016/j. jfoodeng.2005.03.026.

Chien, P. J., Sheu, F., \& Lin, H. R. (2007). Coating citrus (Murcott tangor) fruit with low molecular weight chitosan increases postharvest quality and shelf life. Food Chemistry, 100(3), 1160-1164. http:// dx.doi.org/10.1016/j.foodchem.2005.10.068.

Evans, P., \& Halliwell, B. (2001). Micronutrients: oxidant/antioxidant status. British Journal of Nutrition, 85(S2, Suppl 2), 67-74. http:// dx.doi.org/10.1079/BJN2000296. PMid:11509092. 
Ismail, A., Marjan, Z., \& Foong, C. (2004). Total antioxidant activity and phenolic content in selected vegetables. Food Chemistry, 87(4), 581-586. http://dx.doi.org/10.1016/j.foodchem.2004.01.010.

Kelebek, H., Selli, S., Canbas, A., \& Cabaroglu, T. (2009). HPLC determination of organic acids, sugars, phenolic compositions and antioxidant capacity of orange juice and orange wine made from a turkish cv. Kozan. Microchemical Journal, 91(2), 187-192. http:// dx.doi.org/10.1016/j.microc.2008.10.008.

Ladaniya, M. S. (2008). Citrus fruit: biology, technology and evaluation. San Diego: Academic Press.

Mishra, K., Ojha, H., \& Chaudhury, N. K. (2012). Estimation of antiradical properties of antioxidants using DPPH assay: a critical review and results. Food Chemistry, 130(4), 1036-1043. http://dx.doi. org/10.1016/j.foodchem.2011.07.127.

Okwi, D. E., \& Emenike, I. N. (2006). Evaluation of the phytonutrients and vitamins contents of citrus fruits. International Journal of Molecular Medicine and Advanced Sciences, 2(1), 1-6.

Ortuño, A., Reynaldo, I., Fuster, M. D., Botía, J., Puig, D. G., Sabater, F., Lidón, A. G., Porras, I., \& Del-Río, J. (1997). Citrus cultivars with high flavonoid contents in the fruits. Scientia Horticulturae, 68(1-4), 231-236. http://dx.doi.org/10.1016/S0304-4238(96)00988-0.

Paudyal, K. P., \& Haq, N. (2008). Variation of pomelo (Citrus grandis (L.) Osbeck) in Nepal and participatory selection of strains for further improvement. Agroforestry Systems, 72(3), 195-204. http:// dx.doi.org/10.1007/s10457-007-9088-z.

Petropoulos, S. A., Pereira, C., Ntatsi, G., Danalatos, N., Barros, I., \& Ferreira, I. C. (2018). Nutritional value and chemical composition of greek artichoke genotypes. Food Chemistry, 267, 296-302. http:// dx.doi.org/10.1016/j.foodchem.2017.01.159. PMid:29934171.

Rouse, R. E. (2000). Citrus fruit quality and yield of six valencia clones on 16 rootstocks in the immokalee foundation grove. Proceedings of the Annual Meeting of the Florida State Horticultural Society, $113,112-114$.
Rusak, G., Komes, D., Likic, S., Horzic, D., \& Kovac, M. (2008). Phenolic content and antioxidative capacity of green and white tea extracts depending on extraction conditions and solvent used. Food Chemistry, 110(4), 852-858. http://dx.doi.org/10.1016/j.foodchem.2008.02.072. PMid:26047270.

Seymour, G. B., Taylor, J. E., \& Tucker, G. A. (2012). Biochemistry of fruit ripening. Netherlands: Springer.

Siddique, M. I., \& Garnevska E. (2017). Agricultural value chain. In M. I. Siddique \& E. Garnevska, Citrus value chain(s): a survey of Pakistan citrus industry (pp. 37-56). London: IntechOpen.

Song, S. Y., Lee, Y. K., \& Kim, I. J. (2016). Sugar and acid content of citrus prediction modeling using $\mathrm{ft}$-ir fingerprinting in combination with multivariate statistical analysis. Food Chemistry, 190, 1027-1032. http://dx.doi.org/10.1016/j.foodchem.2015.06.068. PMid:26213071.

Steel, R. G. D., Torrie, J. H., \& Dickey, D. A. (1997). Principles and procedures of statistics: a biometrical approach (3rd ed.). New York: McGraw Hill.

Texeira, D. C., Ayres, J., Kitajima, E. W., Danet, L., Jagoueix-Eveillard, S., Saillard, C., \& Bové, J. M. (2005). First report of a huanglongbinglike disease of citrus in São Paulo State, Brazil and association of a new liberibacter species, "Candidatus Liberibacter americanus", with the disease. Plant Disease, 89(1), 107-107. http://dx.doi.org/10.1094/ PD-89-0107A. PMid:30795297.

Toh, J. J., Khoo, H. E., \& Azrina, A. (2013). Comparison of antioxidant properties of pomelo [Citrus grandis (L.) osbeck] varieties. International Food Research Journal, 20(4), 1661-1668.

Xu, G. D., Liu, J., Chen, X., Ye, Y., Ma, Y., \& Shi, J. (2008). Juice components and antioxidant capacity of citrus varieties cultivated in china. Food Chemistry, 106(2), 545-551. http://dx.doi.org/10.1016/j. foodchem.2007.06.046.

Zou, Z., Xi, W., Hu, Y., Nie, C., \& Zhou, Z. (2016). Antioxidant activity of citrus fruits. Food Chemistry, 196, 885-896. http://dx.doi.org/10.1016/j. foodchem.2015.09.072. PMid:26593569. 